\title{
EFFECT OF BREED AND AGE ON HISTOPATHOLOGICAL CHANGES IN PIG M. SEMIMEMBRANOSUS*
}

\author{
Dorota Wojtysiak ${ }^{1}$, Katarzyna Połtowicz ${ }^{2}$, Władysław Migdał ${ }^{3}$ \\ ${ }^{1}$ Department of Reproduction and Animal Anatomy, Agricultural University of Krakow, \\ Al. Mickiewicza 24/28, 30-059 Kraków, Poland \\ ${ }^{2}$ Department of Animal Genetics and Breeding, National Research Institute of Animal Production, \\ 32-083 Balice n. Kraków, Poland \\ ${ }^{3}$ Department of Animal Products Technology, Agricultural University of Krakow, Balicka 122, \\ 31-149 Kraków, Poland
}

\begin{abstract}
The aim of the study was to determine the type and extent of histopathological changes in $\mathrm{m}$. semimembranosus of Polish Landrace (PL), Polish Large White (PLW), Duroc, Pietrain, and Pulawska pigs at $60,90,120,150,180$ and 210 days of age. Changes in fibre size (atrophy, hypertrophy - giant fibres), changes in fibre shape (angular fibres), degenerative lesions (necrosis with phagocytosis) and connective tissue hypertrophy were evaluated. The presence of giant fibres was the only histopathological change observed in all age groups of PL, PLW, Duroc and Pietrain pigs, with the percentage of pigs with this type of pathology and the frequency of giant, atrophic and angular fibres increasing significantly with age. In Puławska pigs, giant fibres were only found in the oldest pigs aged 210 days. In these animals, giant fibres as well as atrophic fibres (at 180 and 210 days of age) and angular fibres (at 120, 150, 180 and 210 days of age) occurred in the smallest number of animals and were least extensive. Meanwhile, Pietrain pigs were characterized by a greater number of animals, a significantly greater proportion of giant fibres in all analysed age groups, and a greater proportion of atrophic fibres at 180 and 210 days of age compared to the other pig breeds under analysis. For connective tissue hypertrophy and necrosis with phagocytosis, the changes were not extensive. It is concluded that both the advancing age of the animals and selection of the pigs for increased leanness significantly increases the incidence of histopathological changes in muscle tissue, which may directly translate into pork quality.
\end{abstract}

Key words: breed, age, histopathological changes, $m$. semimembranosus, pigs

The main objective of selective breeding of pigs is to increase the efficiency of production by achieving high rate of growth and high meat production. Genetic improvement of protein deposition enabled the weight of different muscle parts to be

\footnotetext{
*This study was supported by the grant No. N311 086034.
} 
increased in high-lean pigs. However, a negative relationship between the quantity and quality of meat is increasingly seen. Advances in improvement of muscle mass contributed to the emergence of pathological features in muscle tissue microstructure, leading to meat quality defects in the carcass parts highly desired by the meat industry, such as longissimus muscle, m. quadriceps femoris and m. semimembranosus (Wegner et al., 1993). The importance of the problem is evidenced by a study of Pospiech et al. (1998), which shows that economic losses due to deteriorating meat quality may sometimes outweigh the profit from increased carcass leanness. Research on muscle tissue microstructure offers some hope that the problem of increasing pig leanness and decreasing meat quality will be explained. In addition to high cognitive value, the association between muscle microstructure and physicochemical parameters may be of great practical importance, because it may explain the determinants of leanness and meat quality problems. The main histopathological changes of muscle tissue are muscle fibre atrophy, necrosis and connective tissue hypertrophy. A considerable proportion of pathological abnormalities also includes changes in shape or muscle fibre hypetrophy and the emergence of giant fibres. Earlier studies demonstrated that high-lean animals have a greater risk of meat defects such as PSE and DFD, which are accompanied by pathological changes in muscle tissue (Sośnicki, 1987; Kłosowska et al., 1995). These defects are associated with susceptibility of animals to stressors, which have an effect on the quality of raw material obtained. The incidence of histopathological changes in muscle tissues also largely depends on the composition of muscle fibres (Rahelič and Pauc, 1980; Solomon and West, 1985; Kłosowska et al., 1995). Much evidence shows that the type and extent of histopathological changes may also have a genetic background (Wimmers et al., 2006), and depend on the breed (Kłosowska et al., 1995; Walasik et al., 2000; Bogucka et al., 2006; Schubert-Schoppmeyer et al., 2008; Sobczak et al., 2010), age and body weight of animals (Wojtysiak and Migdał, 2006). Knowledge of muscle tissue microstructure, in particular the type and extent of pathological changes, may thus become an important part of the appropriate and objective assessment of meat quality or a method that validates or supports existing assessment methods.

Therefore, the aim of the study was to determine the type and extent of histopathological changes in $m$. semimembranosus from five breeds of pigs depending on their age.

\section{Material and methods}

A total of 300 fatteners representing five breeds: Polish Landrace (PL), Polish Large White (PLW), Duroc, Pietrain, and Puławska were used in this study (30 gilts and 30 barrows of each breed). Animals were kept from 60 to 210 days of age at the Agricultural Production Cooperative in Kędzierzyn-Koźle, Poland, and fed a complete diet. All animals were reared under the same environmental and production regime. Pigs of each breed were slaughtered at 60, 90, 120, 150, 180 and 210 days of age ( 5 gilts and 5 barrows of each age from each breed) in a commercial slaughterhouse 
belonging to the Agricultural Production Cooperative in Kędzierzyn-Koźle. Feed was withdrawn $12 \mathrm{~h}$ before slaughter but water was freely available in lairage. The pigs were stunned with $\mathrm{CO}_{2}$ and processed according to the normal slaughterhouse procedures (exsanguinated, scalded, dehaired and eviscerated). Muscle samples were taken 45 min postmortem from the right carcass side deep within the semimembranosus muscle and frozen in isopentane that was cooled using liquid nitrogen and stored at $-80^{\circ} \mathrm{C}$ until histochemical analysis. Serial transverse sections of $10 \mu \mathrm{m}$ were cut at $-20^{\circ} \mathrm{C}$ in a cryostat (Slee MEV, Germany) and stained by haematoxylin and eosin. Further sections were exposed to a histochemical reaction for NADH-tetrazolium reductase (NADH-TR), which enables classification of type I, IIA and IIB muscle fibres (Dubowitz and Sewery, 2007). The histopathological changes were assessed by analysing 10 pictures of muscle samples of $1000 \mu \mathrm{m}^{2}$ area each using a NIKON E600 (Japan) light microscope. According to Dubowitz and Sewery (2007) the following histopathological changes were examined: changes in fibre size (atrophy, hypertrophy - giant fibres) and shape (angular fibres), degenerations (necrosis with phagocytosis) and connective tissue hypertrophy (fibrosis).

The percentage of histopathological changes and diameter of giant fibres and their classification as I, IIA and IIB types were determined by image analysis (Multi Scan v. 14.02). A minimum of 300 muscle fibres per sample were counted except connective tissue, which was estimated subjectively according to the following scale: "0" - no change, "+" - minor change and "++" - major change.

The results obtained were subjected to a statistical evaluation with the STATGRAPHICS 4.1 software. A multifactor analysis of variance was conducted and significance of differences identified with the Tukey's test.

\section{Results}

Histological analysis showed the presence of pathological changes such as changes in fibre size (giant and atrophic fibres), changes in fibre shape (angular fibres), degenerative changes (necrosis with phagocytosis) and connective tissue hypertrophy (Figures 1-4).

Percentages of PLW, PL, Puławska, Duroc and Pietrain pigs that showed histopathological changes of varying extent in m. semimembranosus at 60, 90, 120, 150, 180 and 210 days of age are presented in Tables 1 and 2.

In the present study, giant fibres were the only pathological change of muscle tissue to occur in all age groups of PLW, PL, Duroc and Pietrain fatteners, with the percentage of pigs with this type of pathological abnormalities and frequency of giant fibres increasing with age. In Puławska pigs, the presence of giant fibres and their lowest frequency compared to the other pig breeds were found in the oldest animals aged 210 days. Moreover, in all age groups, the largest number of animals and significantly highest frequency of giant fibres in the analysed muscles were characteristic of the Pietrain pigs. In the microscopic image, giant fibres are characterized by round or oval shape and homogeneous cytoplasmic structure. They were found 
to be located primarily at the edge of, and, less frequently, within primary muscle bundles. Moreover, giant fibres showed a higher staining intensity after exposure to eosin compared with surrounding normal fibres (Figure 4). Meanwhile, the staining results of the giant fibre type classification by NADH-TR reaction (Figures $5 \mathrm{a}-\mathrm{c}$ ) showed that only type IIB giant fibres are found in the $m$. semimembranosus of PLW, PL, Duroc and Pietrain pigs aged 60, 90 and 120 days. In another age group, type IIA giant fibres were found at 150 days of age. Type I giant fibres were also found in 180- and 210-day-old PL, Duroc and Pietrain pigs. In Puławska pigs giant fibres were exclusively of type IIB.
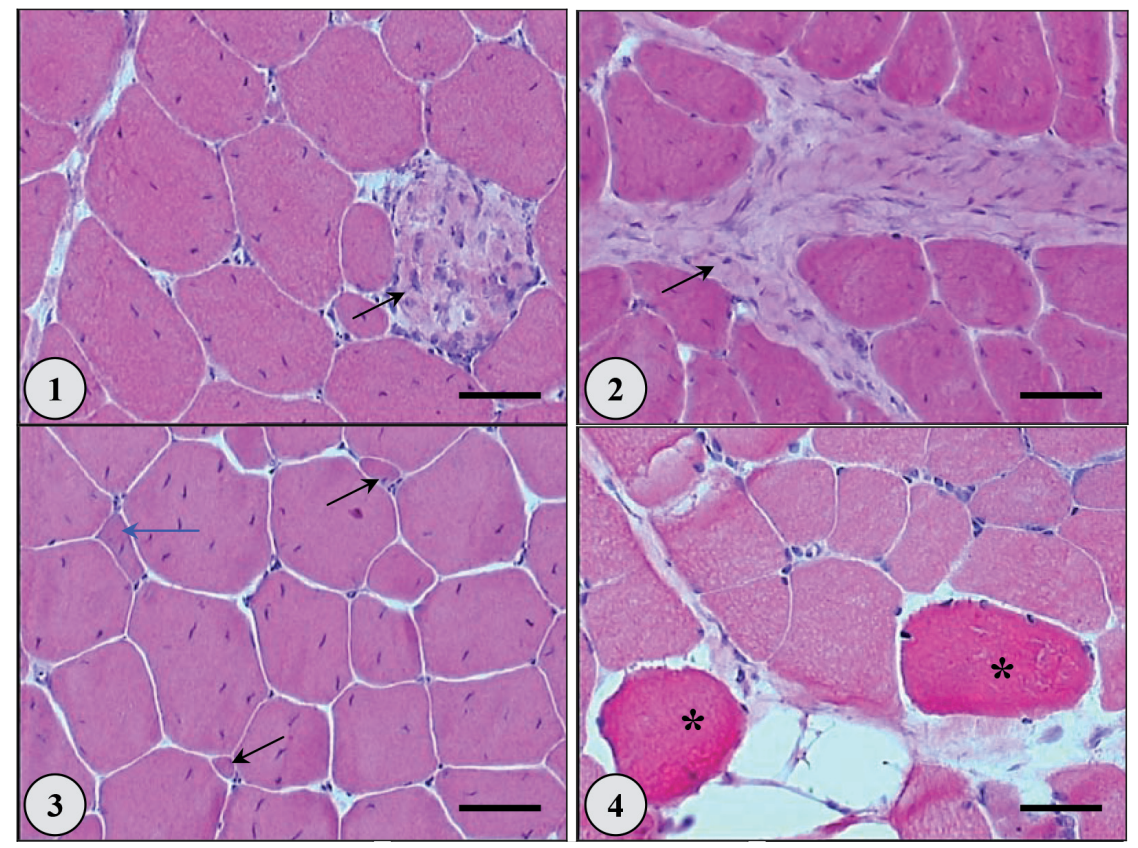

Figures 1-4. Exemplary cross-section of $m$. semimembranosus stained for hematoxylin-eosin: 1 - Fibre necrosis with phagocytosis (arrow); 2 - Connective tissue hypertrophy (arrow); 3 - Atrophy (black arrow) and angular fibres (blue arrow); 4 - Giant fibres (*). Scale bar $50 \mu \mathrm{m}$.

As regards muscle fibre atrophy and changes in fibre shape, these pathological changes were found in m. semimembranosus in all analysed pig breeds at 120, 150, 180 and 210 days of age. In the same pigs, atrophy was the most extensive histopathological change. In addition, our study showed the presence of muscle fibre atrophy only in younger Pietrain pigs aged 90 days. In the next age groups under analysis, both the number of animals that show atrophic changes in $m$. semimembranosus and changes in fibre shape, as well as the extent of these changes increase gradually as pigs grow older. Accordingly, at 210 days of age, muscle fibre atrophy was observed in all Pietrain and Duroc pigs, and in most PL and PLW pigs (90\%). Moreover, the 
present study showed that breed of pigs has a significant effect on the frequency of atrophic fibres. Accordingly, at 180 and 210 days of age this change occurred in the smallest number of animals and was least extensive in Puławska pigs, whereas in Pietrain pigs the frequency of atrophic fibres in $m$. semimembranosus formed the largest proportion compared to the other breeds of pigs under analysis. Breed had no significant effect on atrophic fibre frequency in pigs aged 120 and 150 days. In the case of fibre shape change in the muscles of 120-, 150-, 180- and 210-day-old pigs, the smallest number of animals and the significantly lowest percentage of angular fibres were found in Puławska pigs compared to the other breeds.

Table 1. Percentage of pigs showing histopathological changes in semimembranosus muscle

\begin{tabular}{|c|c|c|c|c|c|c|}
\hline & Age/traits & PL & PLW & Duroc & Pietrain & Puławska \\
\hline 60 & $\begin{array}{l}\text { Giant fibres (\%) } \\
\text { Giant fibres of type I/IIA/IIB (\%) } \\
\text { Angular fibres (\%) } \\
\text { Atrophic fibres (\%) } \\
\text { Necrosis with phagocytosis (\%) } \\
\text { Fibrosis (\%) }\end{array}$ & $\begin{array}{c}10 \\
0 / 0 / 10 \\
0 \\
0 \\
0 \\
0\end{array}$ & $\begin{array}{c}10 \\
0 / 0 / 10 \\
0 \\
0 \\
0 \\
0\end{array}$ & $\begin{array}{c}20 \\
0 / 0 / 20 \\
0 \\
0 \\
0 \\
0\end{array}$ & $\begin{array}{c}30 \\
0 / 0 / 30 \\
0 \\
0 \\
0 \\
0\end{array}$ & $\begin{array}{c}0 \\
0 / 0 / 0 \\
0 \\
0 \\
0 \\
0\end{array}$ \\
\hline 90 & $\begin{array}{l}\text { Giant fibres }(\%) \\
\text { Giant fibres of type I/IIA/IIB (\%) } \\
\text { Angular fibres (\%) } \\
\text { Atrophic fibres (\%) } \\
\text { Necrosis with phagocytosis (\%) } \\
\text { Fibrosis (\%) }\end{array}$ & $\begin{array}{c}20 \\
0 / 0 / 20 \\
0 \\
0 \\
0 \\
0\end{array}$ & $\begin{array}{c}10 \\
0 / 0 / 10 \\
0 \\
0 \\
0 \\
0\end{array}$ & $\begin{array}{c}20 \\
0 / 0 / 20 \\
0 \\
0 \\
0 \\
0\end{array}$ & $\begin{array}{c}30 \\
0 / 0 / 30 \\
0 \\
10 \\
10 \\
20\end{array}$ & $\begin{array}{c}0 \\
0 / 0 / 0 \\
0 \\
0 \\
0 \\
0\end{array}$ \\
\hline 120 & $\begin{array}{l}\text { Giant fibres (\%) } \\
\text { Giant fibres of type I/IIA/IIB (\%) } \\
\text { Angular fibres (\%) } \\
\text { Atrophic fibres (\%) } \\
\text { Necrosis with phagocytosis (\%) } \\
\text { Fibrosis (\%) }\end{array}$ & $\begin{array}{c}20 \\
0 / 0 / 20 \\
30 \\
20 \\
10 \\
20\end{array}$ & $\begin{array}{l}20 \\
0 / 0 / 20 \\
20 \\
30 \\
10 \\
20\end{array}$ & $\begin{array}{c}30 \\
0 / 0 / 30 \\
30 \\
30 \\
20 \\
30\end{array}$ & $\begin{array}{c}40 \\
0 / 0 / 40 \\
20 \\
30 \\
10 \\
20\end{array}$ & $\begin{array}{c}0 \\
0 / 0 / 0 \\
10 \\
20 \\
0 \\
10\end{array}$ \\
\hline 150 & $\begin{array}{l}\text { Giant fibres (\%) } \\
\text { Giant fibres of type I/IIA/IIB (\%) } \\
\text { Angular fibres (\%) } \\
\text { Atrophic fibres (\%) } \\
\text { Necrosis with phagocytosis (\%) } \\
\text { Fibrosis (\%) }\end{array}$ & $\begin{array}{c}30 \\
0 / 10 / 20 \\
40 \\
40 \\
20 \\
30\end{array}$ & $\begin{array}{c}30 \\
0 / 10 / 30 \\
30 \\
30 \\
10 \\
20\end{array}$ & $\begin{array}{c}40 \\
0 / 10 / 40 \\
40 \\
40 \\
10 \\
20\end{array}$ & $\begin{array}{c}60 \\
0 / 20 / 50 \\
40 \\
50 \\
20 \\
30\end{array}$ & $\begin{array}{c}0 \\
0 / 0 / 0 \\
20 \\
30 \\
10 \\
10\end{array}$ \\
\hline 180 & $\begin{array}{l}\text { Giant fibres (\%) } \\
\text { Giant fibres of type I/IIA/IIB (\%) } \\
\text { Angular fibres (\%) } \\
\text { Atrophic fibres }(\%) \\
\text { Necrosis with phagocytosis }(\%) \\
\text { Fibrosis }(\%)\end{array}$ & $\begin{array}{c}60 \\
10 / 20 / 50 \\
50 \\
80 \\
10 \\
30\end{array}$ & $\begin{array}{c}50 \\
0 / 20 / 40 \\
50 \\
70 \\
20 \\
30\end{array}$ & $\begin{array}{c}60 \\
10 / 20 / 40 \\
60 \\
80 \\
10 \\
20\end{array}$ & $\begin{array}{c}80 \\
20 / 30 / 70 \\
70 \\
90 \\
20 \\
30\end{array}$ & $\begin{array}{c}0 \\
0 / 0 / 0 \\
40 \\
50 \\
10 \\
10\end{array}$ \\
\hline 210 & $\begin{array}{l}\text { Giant fibres (\%) } \\
\text { Giant fibres of type I/IIA/IIB (\%) } \\
\text { Angular fibres (\%) } \\
\text { Atrophic fibres (\%) } \\
\text { Necrosis with phagocytosis (\%) } \\
\text { Fibrosis (\%) }\end{array}$ & $\begin{array}{l}70 \\
10 / 30 / 50 \\
70 \\
90 \\
20 \\
20\end{array}$ & $\begin{array}{c}60 \\
0 / 10 / 50 \\
60 \\
90 \\
30 \\
30\end{array}$ & $\begin{array}{c}70 \\
10 / 20 / 50 \\
70 \\
100 \\
20 \\
30\end{array}$ & $\begin{array}{c}100 \\
20 / 40 / 80 \\
80 \\
100 \\
30 \\
20\end{array}$ & $\begin{array}{c}10 \\
0 / 0 / 10 \\
50 \\
60 \\
20 \\
20\end{array}$ \\
\hline
\end{tabular}




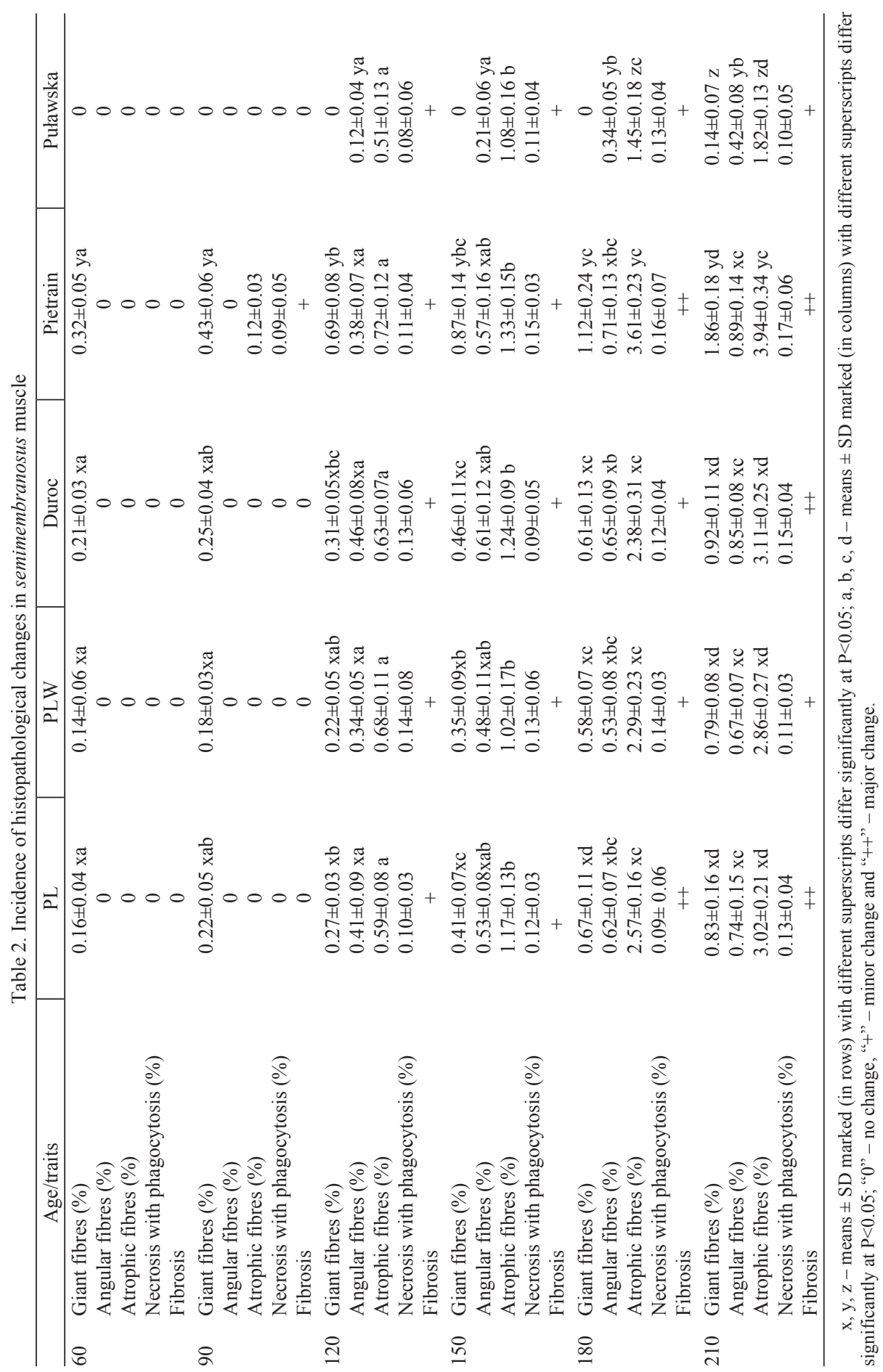



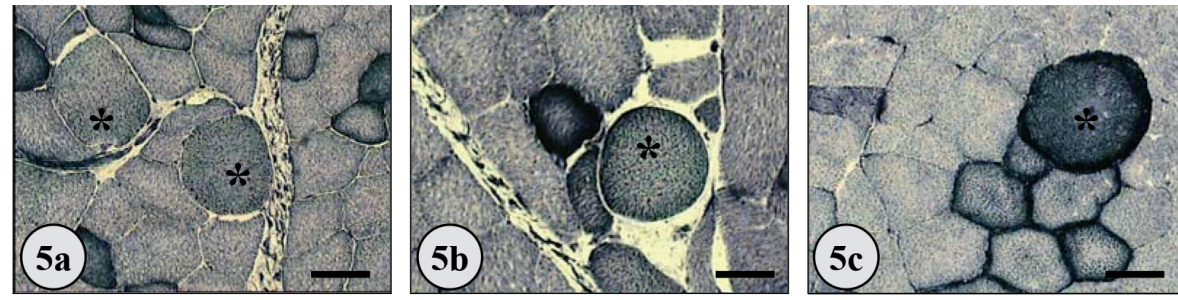

Figures 5a-c. Exemplary cross-section of m. semimembranosus stained for NADH-TR activity: Giant fibres $(*)$ type IIB -5 a; type IIA -5 b and type I -5 c. Scale bar $50 \mu \mathrm{m}$.

In the case of connective tissue hypertrophy and necrosis with phagocytosis, the changes observed in our study were characterized by the lowest intensity and were not extensive. In the youngest animals aged 60 days, no such changes were found in any of the analysed pig breeds. At 90 days of age, necrosis with phagocytosis and connective tissue hypertrophy were only found in the muscles of Pietrain pigs. In the next age group (120 days), these changes were also found in PLW, PL and Duroc pigs. In the group of pigs aged 150 days and older, necrosis with phagocytosis and connective tissue hypertrophy were observed in all analysed pig breeds, with both the breed and age of animals having no significant effect on percentage of degenerative changes.

\section{Discussion}

One of the major pathological changes of muscle tissue that directly translates into meat quality is muscle fibre hypertrophy (giant fibres). Earlier research showed that giant fibre frequency and size is significantly related to meat acidity and texture parameters (Fazarinc et al., 2002; Schubert-Schoppmeyer et al., 2008; Sobczak et al., 2010). Giant fibres have been described as hypercontracted fibres or hypercontracted fibre regions and are only detected postmortem, not in vivo (Solomon and Eastridge, 1987). The development of these fibres is the subject of controversy. Bergmann (1979) described this process as the consequence of the exposure to stress, whereas Sośnicki (1987) considered their development to be a result of a degenerative process. Kłosowska et al. (1995) believe that formation of giant fibres is associated with nervous excitation, suggesting that they may be a preliminary stage of hyaline degeneration. Fazarinc et al. (2002) suppose that giant fibre formation is a result of excessive intracellular lactate accumulation in some fast-twitch glycolytic fibres. In our study, the increase in the frequency of giant fibres in $m$. semimembranosus and in the percentage of PL, PLW, Duroc and Pietrain pigs that showed this type of pathology with advancing age is probably associated with the increase in the body weight of pigs (Wojtysiak and Migdał, 2006). Meanwhile, the results obtained for Puławska pigs, in which giant fibres were only observed in the oldest pigs (at 210 days of age) together with the smallest number of animals showing this type of changes and the 
smallest extent of these changes, compared to the other breeds of pigs analysed, are in agreement with an earlier study by Schubert-Schoppmeyer et al. (2008), who showed that pigs of native breeds are characterized by a lower percentage of giant fibres compared to specialized meat-type pigs. Velotto et al. (2007) found no giant fibres in the muscles of the native breed of Black Sicilian pigs, which may explain the lack of giant fibres in Puławska pigs between 60 and 180 days of age. Meanwhile, the largest number of animals together with the highest frequency of giant fibres in $m$. semimembranosus of Pietrain pigs in all age groups analysed are consistent with an earlier study by Schubert-Schoppmeyer et al. (2008), who showed that the proportion of giant fibres in $m$. longissimus of Pietrain pigs was significantly higher compared to Large White, Landrace and Leicoma pigs. Likewise, Sobczak et al. (2010) noted a higher frequency of giant fibres in the muscles of Pietrain pigs. Moreover, the same authors observed that a decrease of Pietrain genes in the crossbred genotype reduced the number of giant fibres in comparison with the pure Pietrain breed. Recent research suggests that the emergence of giant fibres and their number are in part genetically determined (Wimmers et al., 2006). Fazarinc et al. (2002) noted that the incidence of giant fibres was the highest in RYR1 dimutant pigs (RYR1 nn). Similarly, Fiedler et al. (1999) suggested that the presence of giant fibres in muscles of high meatiness is connected with the HAL gene and stress susceptibility. Studies by Kłosowska et al. (1995) and Brym et al. (2002) revealed that it is the highly selected Pietrain breed that shows the highest stress susceptibility. Meanwhile, the histochemical analysis of giant fibres in our study confirmed the earlier observations of Schmitt and Dumont (1981) and Schubert-Schoppmeyer et al. (2008), which showed that giant fibres may form from each type of muscle fibres (I, IIA and IIB), with the formation of giant fibres from type IIB fibres being the most common.

Our analysis of pathological changes in muscle tissue such as atrophy and change in fibre shape confirms the earlier observations that muscle fibre atrophy forms the largest proportion of all pathological changes observed in porcine muscles (Walasik et al., 2000; Bogucka et al., 2006; Wojtysiak and Migdał, 2006). Atrophy is a gradual reduction in muscle fibre volume, which is paralleled by a loss of both myofibrils and sarcoplasm (Hausmanowa-Petrusewicz, 1993; Paciello and Papparella, 2009; Thuilliez et al., 2009). In addition, the present results show that the age of animals and therefore their body weight have a significant effect on the frequency of atrophic changes and on changes in the shape of muscle fibres in $m$. semimembranosus. It may explain the lack of this type of changes in the youngest animals and the significant increase in both percentage and extent of atrophic changes, as well as the changes in fibre shape with advancing age of the pigs. These suppositions are confirmed by our earlier research (Wojtysiak and Migdał, 2006), in which analysis of the effect of body weight on the extent of histopathological changes in $m$. longissimus of pigs revealed a significantly higher proportion of angular fibres in heavier fatteners. Wimmers et al. (2006) suggest that the emergence of angular fibres in porcine muscles may also have a genetic background. What is more, the differences observed in the present study between the analysed pig breeds in the proportion of atrophic and angular fibres indicate that selection of pigs for increased leanness contributes to the increased incidence of pathological changes in muscle tissue. 
Of all the analysed histopathological changes found in $m$. semimembranosus, necrosis with phagocytosis was the least frequent (less than $0.1 \%$ animals). Importantly, our results confirm the earlier observations (Walasik et al., 2000; Bogucka et al., 2006; Paciello and Papparella, 2009) that this process is often paralleled by connective tissue hypertrophy. What is more, our observations indicate that necrosis with phagocytosis and connective tissue hypertrophy occur gradually with age of the pigs, as evidenced by the lack of this type of changes in the youngest animals aged 60 days, while in older animals degenerative changes emerge gradually, with both necrosis with phagocytosis and connective tissue hypertrophy being observed at 150 days of age in all pig breeds analysed. Importantly, however, neither breed nor age of animals had a significant effect on the frequency of fibres affected by necrosis with phagocytosis. Similarly Bogucka et al. (2006), who analysed the extent of histopathological changes in $m$. semimembranosus of hybrid pigs derived from the Dutch Stamboek and Polish Torhyb production programmes, found no significant differences between them in percentage of fibres affected by necrosis with phagocytosis. In the case of fibrosis, the changes observed in the present study were not extensive except the oldest Pietrain, Duroc and PL pigs (210 days of age) and 180day-old Pietrain and PL pigs, where fibrosis was more extensive.

It is concluded that both the breed and age of pigs have a significant effect on the type and extent of histopathological changes. As pigs grow older, the percentage of pigs with histopathological changes (giant, atrophic and angular fibres) in $m$. semimembranosus and the frequency of these changes increase. Furthermore, the results obtained indicate that selection of the pigs for increased leanness significantly increases the incidence of giant, atrophic and angular fibres in muscle tissue.

\section{References}

B e r g m a n n V. (1979). Changes of cardiac and skeletal muscle in pigs following transport stress. Exp. Pathol., 17: 243-248.

B o g u c k a J., W a la s i k K., E 1 m in ow s k a - W e n d a G., K r u c z yń s k a M. (2006). Pathological changes in the structure of semimembranosus muscle from pigs included in the Stamboek and Torhyb breeding programmes. Anim. Sci. Pap. Rep., Suppl., 2, 24: 45-52.

B ry m P., Ka miński S., Rus c A., Wój c ik E. (2002). Allele frequency in ryanodine receptor (RYR1) locus in boars of different breeds. Ann. Anim. Sci., Suppl., 2: 33-35.

D ubowitz V., S e w e ry C.A. (2007). Muscle Biopsy: A Practical Approach. 3rd edition, Saunders Elsevier.

Fazarinc G., Čandek-Potokar M., Uršič M., Vrecl M., Pogačnik A. (2002). Giant muscle fibres in pigs with different RYR 1 genotype. Anat. Histol. Embryol., 31: 367-371.

F i e d l e r I., En d e r K., W i c k e M., M a k S., v o n L e r g en ken G., M e y e r W. (1999). Structural and functional characteristics of muscle fibres in pigs with different malignant hyperthermia susceptibility (MHS) and different meat quality. Meat Sci., 53: 9-15.

Ha u s m a now a - P etrus ew i c z I. (1993). Muscle diseases (in Polish). PZWL, Warszawa.

Kło s ows ka D., Kłosowski B., N ow a k B. (1995). Histopathological changes in longissimus muscle of Pietrain pigs and its crosses. Proceedings of the 2nd Dummerstorf Muscle Workshop on Muscle Growth and Meat Quality, Rostock, 17-19 May 1995, pp. 84-91.

P a c i e 11 o O., P a p p a r e 11 a S. (2009). Histochemical and immunohistochemical approach to comparative neuromuscular diseases. Folia Histochem. Cytobiol., 47: 143-152. 
Pospiech E., Borzuta K., Łyczyński A., Plókarz W. (1998). Meat defects and their economic importance. Pol. J. Food Nutr. Sci., 7/48, 4: 7-20.

Rahelič S., P a uc S. (1980). Fibre types in longissimus dorsi from wild and highly selected pig breeds. Meat Sci., 50, p. 431.

$\mathrm{S} \mathrm{chmitt}$ O., D u m o n t B.L. (1981). Detection of giant fibres and interpretation of their presence in pig muscle. In Proceedings of the Symposium Agricultural Food Research Society, As, Norway, pp. 53-58.

Schubert-Schoppmeyer A., Fi ed ler I., N ürnberg G., Jon as L., Ender K., Ma ak S., $\mathrm{Rehfeldt} \mathrm{C.} \mathrm{(2008).} \mathrm{Simulation} \mathrm{of} \mathrm{giant} \mathrm{fibre} \mathrm{development} \mathrm{in} \mathrm{biopsy} \mathrm{samples} \mathrm{from} \mathrm{pig} \mathrm{longis-}$ simus muscle. Meat Sci., 80: 1297-1303.

Sobczak M., Lachowicz K., Żochowska-Kujawska J. (2010). The influence of giant fibres on utility for production of massaged products of porcine muscle longissimus dorsi. Meat Sci., 84: 638-644.

S o 1 o m on M.B., E as tridge J.S. (1987). Occurrence of giant fibres in muscles from wild pigs native to the United Sates. Meat Sci., 20: 75-81.

S o 1 o m on M.B., W e st R.L. (1985). Profile of fibre types in muscles from wild pigs native to the United States. Meat Sci. 13: 247-254.

S o śn i c k i A. (1987). Histopathological observation of stress myopathy in M. longissimus in the pig and relationships with meat quality, fattening and slaughter traits. J. Anim. Sci., 65: 584-596.

Thuilliez C., Dorso L., Howroyd P., Gould S., Chanut F., Burnett R. (2009). Histopathological lesions following intramuscular administration of saline in laboratory rodents and rabbits. Exp. Toxicol. Pathol., 61: 13-21.

Velotto S., Varricchio E., Di Pris co M.R., Stasi T., Crasto A. (2007). Skeletal myocyte types and vascularity in the Black Sicilian pig. Acta Vet. Brno., 76: 163-170.

W a l a s i k K., K ł o s ow sk a D., G r z e śk o w i a k E. (2000). Pathological changes in musculus longissimus lumborum of hybrid pigs with Hampshire genes (in Polish). Rocz. Nauk. Zoot., Suppl., 6: 233-237.

W e g n e r J., F i e d l e r.I., Kło s ow sk a D., K ł o s ow sk i B., Z i e gan B. (1993). Veranderungen der Muskelfasertypenverteilung im M. longissimus dorsi von Ebern während des Wachstums dargestellt mit verschiedenen histochemischen Methoden. Anat. Histol. Embryol., 22: 355-359.

Wimmers K., Fiedler I., Hardge T., Murani E., Schellander K., Ponsuksili S. (2006). QTL for microstructural and biophysical muscle properties and body composition in pigs. BMC Genetics, 7, p. 15.

W o j ty s i a k D., M ig d a 1 W. (2006). Effect of body weight on histopathological changes in $m$. longissimus lumborum of fatteners. Anim. Sci., Suppl., 2: 451-455.

Accepted for printing 19 III 2012

DOROTA WOJTYSIAK, KATARZYNA POŁTOWICZ, WŁADYSŁAW MIGDAŁ

Wpływ rasy i wieku na zmiany histopatologiczne w m. semimembranosus świń

STRESZCZENIE

Celem pracy było określenie rodzaju i rozległości zmian histopatologicznych $\mathrm{w} \mathrm{m}$. semimembranosus świń ras pbz, wbp, Duroc, Pietrain oraz puławskiej ubijanych w: 60. 90., 120., 150., 180. i 210. dniu życia. Analizowano zmiany wielkości włókien mięśniowych (atrofia, hipertrofia - włókna olbrzymie), zmiany ich kształtu (włókna angularne), zmiany degeneracyjne (martwica z fagocytozą) oraz przerost tkanki łącznej. Stwierdzono, że jedyną zmianą histopatologiczną obserwowaną we wszystkich grupach wiekowych świń ras PL, PLW, Duroc oraz Pietrain była obecność włókien olbrzymich, przy czym zarówno procent świń wykazujących ten rodzaj patologii, jak i frekwencja włókien olbrzymich, a także włókien atroficznych i angularnych wzrastała istotnie wraz z wiekiem. U świń rasy puławskiej 
włókna olbrzymie wykazano wyłącznie u najstarszych świń w 210. dniu życia. U nich też włókna olbrzymie, a także włókna atroficzne (w 180. i 210. dniu życia) oraz angularne (w 120., 150., 180., i 210. dniu życia) występowały u najmniejszej liczby osobników i charakteryzowały się istotnie najmniejszą rozległością. Z kolei świnie rasy Pietrain charakteryzowały się większą liczbą osobników, a także istotnie większym udziałem włókien olbrzymich we wszystkich analizowanych grupach wiekowych, jak również większą proporcją włókien atroficznych w 180. i 210. dniu życia w porównaniu z pozostałymi analizowanymi rasami świń. W przypadku przerostu tkanki łącznej, jak i martwicy z fagocytozą obserwowane w niniejszej pracy zmiany miały niewielki zasięg. Podsumowując, można stwierdzić, iż zarówno wydłużający się wiek zwierząt, jak i selekcja świń w kierunku zwiększenia mięsności wpływają istotnie na wzrost frekwencji występowania zmian histopatologicznych w tkance mięśniowej, co może mieć bezpośrednie przełożenie na jakość mięsa wieprzowego. 